\title{
TORCH Antibody Measurement
}

National Cancer Institute

\section{Source}

National Cancer Institute. TORCH Antibody Measurement. NCI Thesaurus. Code C98602.

A group of blood tests used to detect antibodies to Toxoplasma gondii, rubella,

cytomegalovirus, and herpes simplex virus to rule out congenital infections. A group of

other infections may be tested as well, including varicella-zoster virus, hepatitis B virus,

human immunodeficiency virus, parvovirus B19, and syphilis. 